Special Issue: Agricultural Productivity and Sustainability Improvement in Tropical Region

\title{
Rainy Season's Fish Diversity Upstream and Downstream Jatigede Reservoir of Cimanuk River, West Java, Indonesia
}

\author{
Titin Herawati ${ }^{1 *}$, Indra Adiwiguna $^{1}$, Ayi Yustiati ${ }^{1}$, Iis Rostini $^{1}$, Roy Hendroko Setyobudi ${ }^{2}$, Hafizan Juahir $^{3}$ \\ and Asep Sahidin ${ }^{1}$
}

${ }^{1}$ Department Fisheries, Faculty of Fisheries and Marine Science, Universitas Padjadjaran, Jl. Raya Bandung Sumedang, Hegarmanah, Jatinangor, Bandung 45363, West Java, Indonesia; ${ }^{2}$ Department of Agriculture Science, Postgraduate Program, University of Muhammadiyah Malang, Jl. Raya Tlogomas No 246, Malang 65144, East Java, Indonesia; ${ }^{3}$ East Coast Environmental Research Institut - Sultan Zainal Abidin University, Kampung Gong Badak, 21300, Terengganu, Malaysia.

\begin{abstract}
The purpose of the research is to map the diversity of fish in Cimanuk River, specifically upstream and downstream Jatigede Reservoir. Field observation method and census sampling technique were applied. Research commenced from November 2017 to January 2018. Parameters measured are diversity index, dominance index, equitability index, and water quality. Data analysis employed comparative-descriptive method by mapping the species and comparing the diversity of fish living in both ends of Jatigede Dam. The results indicate that six families of fish are identified, consisting of 14 species. The fish diversity of Cimanuk River upstream Jatigede Reservoir is of moderate one $-1.735 \leq \mathrm{H}^{\prime} \leq 1.909$ - with low species dominance, while containing high equitability $0.61 \leq \mathrm{E} \leq 0.789$ of stable fish community structure. The fish diversity downstream Jatigede Reservoir is of low one $-0.759 \leq \mathrm{H}^{\prime} \leq 0.855$ - with moderate species dominance, while containing low equitability $0.296 \leq \mathrm{E} \leq 0.317$ of distressed fish community structure.

Received | March 03, 2021; Accepted | March 21, 2021; Published | May 21, 2021

*Correspondence | Titin Herawati, Department Fisheries, Faculty of Fisheries and Marine Science, Universitas Padjadjaran, Jl. Raya Bandung Sumedang, Hegarmanah, Jatinangor, Bandung 45363, West Java, Indonesia; Email: titin.herawati@unpad.ac.id

Citation | Herawati, T., I. Adiwiguna, A. Yustiati, I. Rostini, R.H. Setyobudi, H. Juahir and A. Sahidin. 2021. Rainy season's fish diversity upstream and downstream Jatigede Reservoir of Cimanuk River, West Java, Indonesia. Sarhad Journal of Agriculture, 37(Special issue 1): 25-34. DOI | https://dx.doi.org/10.17582/journal.sja/2021/37.s1.25.34

Keywords | Diversity, Environmental, Equitability, Fish map, Water quality.
\end{abstract}

\section{Introduction}

$\mathrm{C}$ imanuk River is one out of three major rivers in West Java, happens to be the second largest after Citarum River. A considerable number of activities for various purposes occur along Cimanuk River; among them are sand mining, water source, hydroelectricity, industrial raw water, irrigation, animal husbandry, and fishery (Andani et al., 2017). Built in the district of Jatigede, Sumedang, and inaugurated on $31^{\text {st }}$ August 2015, Jatigede Reservoir stems the flow of Cimanuk River and has inundated five districts with a total area of 3035.34 ha for its construction.
Such a drastic change may naturally affect the current structure of fish communities along the river, and changes are expected to occur after the construction of the reservoir (Herawati et al. 2017). Earlier, Yuanda (2012) had listed 21 species of fish living along the Cimanuk River: Barb [Barbodes balleroides (Valenciennes, 1842)], Silver barb [Barbodes gonionotus (Bleeker, 1850)], Common barb [Mystacoleuceus marginatus (Valenciennes, 1842)], Hampala barb [Hampala macrolepidota (Kuhl and van Hasselt,1823)], Bonylip (Osteochilus sp.), Silver rasbora [Rasbora argyrotaenia (Bleeker,1850)], Tor duoronensis (Bleeker, 1854), mozambique chiclid [Oreochromis mossambicus 
(W. Peters, 1852)], Nile Tilapia [Oreochromis niloticus (Linnaeus, 1758)], Seren (Cyclocheilichthys sp.), Puntius orphoides (Valenciennes, 1842)], Glyplothorax platypogon (Valenciennes, 1840), Senggal [Mystus nemurus (Valenciennes, 1840), Long whiskers catfish [Mystus gulio/cavasius/ microcanthus (Hamilton, 1822)], Lepidacephalichtys hasselti (Valenciennes, 1846), Bared loach [Nemachilus preifferae (Bleeker, 1853)], Swordtail platy [Xyphophorus helleri (Heckel, 1848)], Walking catfish (Clarias batrachus (Linnaeus, 1758)], Fire eel (Macronathus maeveatus), Spotted scat [Scatophagus argus (Linnaeus 1766)], and Plecos [Hyposarcus pardalis (Castelnau, 1855)].

The list was then updated by Andani et al. (2017), covering as many as nine families of 17 species: Barb (Barbonymus balleroides), Silver rasbora ( $R$. argyrotaenia), Senggal (M. nemurus), Hampala barb (H. macrolepidota), Seren [Cyclocheilichthys repasson (Bleeker, 1855)], Striped snakehead [Channa striata (Bloch, 1793)], Tilapia (O. niloticus), Nile tilapia (O. mosambicus), Common barb (Mystacoleucus marginatus), Bonylip [Osteochilus microcephalus (Valenciennes, 1842)], Fire eel (Mastacembelus erythrotaenia), Bonylip [Osteocbilus vitatus (Valenciennes, in Cuvier and Valenciennes 1842)], Silver barb (B. gonionotus), Three spotted gourme [Trichopodus trichopterus (Pallas, 1770)], Striped catfish [Pangasius hypophthalamus (Sauvage, 1878)], Milk fish [Chanos chanos (Forsskål, 1775)], and Plecos [Pterygoplichthys pardalis Castelnau, 1855)].

The latest record taken by Herawati et al. (2019) during the first inundation process (2015 to 2017) was of 12 families, consisting of 25 species: Barb (B. balleroides) Barb [Barbonymus Schwanenveldii (Bleeker 1854)], Java Barb (B. Orphoides), Silver barb [Systomus gonionotus (Bleeker,1849), Beardless barb [Diplocheilichtys pleurotaenia (Bleeker,1855)], Hampala barb (H. macrolepidota), Common barb (M. marginatus), Bonylip barb (O. vitatus), Bonylip (Osteochillus sp.), Silver rasbora ( $R$. argyrotaenia), Common carp (C. carpio), Tilapia (O. niloticus), Mozambique chiclid (O. Mosambicus), Jaguar guapote [Paracbromis managuensis (Gunther, 1876)], Midas cichlid [Amphilophus citrinellus (Gunther, 1876)], Fire eel (M. erytrotaenia), Walking catfish [Clarias batracus (Linnaeus, 1758)], Three spotted gourme [Trichopodus pectoralis (Regan, 1910)], Striped snakehead (C. striata), Long whiskers catfish (M. gulio), Wrestling half beak [Dermogenys pusilla (Kuhl and van Hasselt, in van Hasselt,1823)], Red bell pacu [Colossoma macropomum (Cuvier, 1816)], Milk fish (C.chanos), Striped catfish (P. hypopthalmus), and Pleco ( $H$. pardalis).

It is noted that during October 2015 to September 2017, 19750600 fish of Barb (B. balleroides), Silver barb (S. gonionotus), Java Barb (B. Orphoides), Bonylip (O. microcephalus), Common carp (C. carpio), Tor sp., Grass carp [Ctenopharyngodon idella (Valenciennes, 1844)], Milk fish (C. chanos), Striped catfish (C. striata), Nile tilapia (O. niloticus), Kissing Gourami [Osphronemus gourami (La Cepede, 1801)], Three spotted gourme (T. pectoralis) and Giant Freshwater Prawn has been introduced to the reservoir water, and the population of Nile tilapia has increased more significantly than other types of fish.

Fish that live in an ecosystem can be grouped according to their demographics, namely native fish, endemic fish, and foreign fish. The Ministry of Marine Affairs and Fisheries Regulation PER.15/Men/2009 defines native fish species as fish and/or other fish resources originating from Indonesia, which are known and/ or known to originate from Indonesia land or sea and originate or live in certain areas and/or different ecosystems in the territorial waters of Indonesia. Fish Quarantine Agency and Fishery Product Quality Control 67/KEP-BKIPM/2015 defines endemic fish as types of fish only found in a certain place and not found in other areas - physical, climatic, and biological factors can cause a change in endemic level, whereas geographical isolation experienced and challenge on living space may cause the organism to become distinctive.

The status of ecosystem determines whether a certain type of fish is considered protected, prohibited, invasive (may apply to either native or foreign fish), or potentially invasive. Invasive foreign species are fish or other organisms that are not part of an ecosystem that can bring negative impact on biodiversity, ecosystem damage, environment, economic losses and/or human health. Furthermore, Ministry of Marine Affairs and Fisheries (2014) states that the entry and spread of such species constitutes a threat that could endanger the preservation of fish's natural resources in the territory of the Republic of Indonesia, since it can directly or indirectly drives native or endemic species to extinction. Spreading to all parts of natural ecosystem, invasive foreign species shall be considered competitor, 
even predator, due to their rapid reproductive ability, adaptability to various environmental conditions that possibly bring dangerous diseases, being all eater, rapid growth, rapid sexual maturity, crossbreeding with lower genetic properties, and negative impact on human health. Invasive species can enter waters in various ways - they may be stocked deliberately with a specific purpose regardless of the cultivation place, carried in ballast water spilled into the waters of the sea, carried as biological pollutants (biofouling) on the hull of the ship, released from new waters, released deliberately from aquariums to the waters, carried on the host species then released into the waters, or released inadvertently after certain research activities (through plant genetic material exchange, biological specimens, microbial culture collections, or laboratory apparatus). In order to avoid the entry of invasive foreign species into Indonesian waters, the government has set forth Regulation of the Ministry of Marine Affairs and Fisheries of the Republic of Indonesia No. 41/PERMEN-KP/2014, concerning the prohibition of Incorporation of Malicious Fish Types from Abroad into the Territory of the Republic of Indonesia. It is defined there that Hazardous fish species are certain fish species originating from outside the territory of the Republic of Indonesia which may harm and/or endanger the preservation of the fish, environment, and human resources.

The current fish diversity in Cimanuk River is the result of invasive species entry and fish stocking activities in Jatigede Reservoir. Additionally, the dam construction cuts the fish migration path off, causing some fish trapped in certain areas. This situation calls for a study to map out fish diversity in the river, specifically upstream and downstream Jatigede Reservoir, of which result should serve as basic data for attempts on fishery resource management and fish resource conservation in Cimanuk River.

\section{Materials and Methods}

The research was conducted in four research Stations: (i) Station I. Bendung Copong, located in Bojong Larang Village, Garut District Garut city, located at coordinates $7^{\circ} 11^{\prime} 22.04^{\prime \prime} \mathrm{S}$ and $107^{\circ} 55^{\prime} 1.23^{\prime \prime} \mathrm{E}$, (ii) Station II. Sasak Beusi Village, District of Limbangan Garut Regency, located at coordinates $7^{\circ}$ 2' 37.98" S and $107^{\circ} 59^{\prime} 18.09^{\prime \prime}$ E, (iii) Station III. Tomo Village, Tomo Sub-District Sumedang District, on coordinates $6^{\circ} 45^{\prime} 43.2^{\prime \prime} \mathrm{S}$ and $108^{\circ} 07^{\prime} 59.4^{\prime \prime} \mathrm{E}$, and (iv) Station IV. Village Pakubeureum, District Kertajati, Majalengka Regency, on the coordinates $6^{\circ} 43^{\prime} 36^{\prime \prime} \mathrm{S}$ and $108^{\circ} 10^{\prime} 30.9^{\prime \prime} \mathrm{E}$.

The method used in this research is Qualitative Quantitative Research Methods in the field (Sugiyono, 2012), employing census sampling technique. Sample taking process was performed once in a month during rainy season from November 2017 to January 2018.

Data taken consists of primary and secondary ones. Primary data - obtained from field observation contains information on catch composition (the fish caught were identified based on the catalogue and core bibliography of the fishes by Kottelat (2013),

Table 1: Water quality parameter.

\begin{tabular}{|c|c|c|c|c|}
\hline Parameter & Unit & Method & Analysis tool & Location of observation \\
\hline \multicolumn{5}{|l|}{ Physical } \\
\hline Current & $\mathrm{m} \mathrm{s}^{-1}$ & & Manual & In situ \\
\hline Temperature & ${ }^{\circ} \mathrm{C}$ & & Thermometer & In situ \\
\hline Light transparency & $\mathrm{cm}$ & & Secchi Disk & In situ \\
\hline Depth & $\mathrm{m}$ & & Manual & In situ \\
\hline Substrate & - & & Manual & In situ \\
\hline \multicolumn{5}{|l|}{ Chemical } \\
\hline $\mathrm{pH}$ & - & Potensiometric & $\mathrm{pH}$ meter & In situ \\
\hline $\mathrm{DO}$ & $\mathrm{mg} \mathrm{L} \mathrm{L}^{-1}$ & Potensiometric & DO meter & In situ \\
\hline Ammonia $\left(\mathrm{NH}_{3}-\mathrm{N}\right)$ & $\mathrm{mg} \mathrm{L} \mathrm{L}^{-1}$ & Spectrophotmetric (SNI 06-6989.30-2005) & Spectrophotometer & Laboratory \\
\hline Nitrite & $\mathrm{mg} \mathrm{L} \mathrm{L}^{-1}$ & Spectrophotmetric (SNI 06-6989.9-2004) & Spectrophotometer & Laboratory \\
\hline \multicolumn{5}{|l|}{ Biology } \\
\hline Fish & Ind & Survei & - & In situ \\
\hline
\end{tabular}


water quality parameters (measured by in-situ and exsitu), interview result with fisherman at each Station to know species and number of fish caught, and fishing gear used by fishermen. Secondary data is in the form of Cimanuk River hydrological data obtained from Cimanuk-Cisanggarung River Basin.Water parameters observed include physical, chemical, and biological parameters as in Table 1 .

\section{Relative abundance}

According to Team Coordinator Komponen I Tenaga Ahli Biodiversity (2013), fish population abundance is calculated using the equation (1):

$$
\mathrm{KR}=\frac{\mathrm{ni}}{\mathrm{N}} \times 100
$$

Where, $K R$ is relative abundance, $n i$ is number of individuals each type, and $N$ is number of individuals all types.

\section{Fish diversity index}

The diversity of fish was calculated using the ShannonWiener Diversity Index (Krebs, 1989) in Amzah et al. (2018); Team Coordinator Komponen I Tenaga Ahli Biodiversity (2013); in equation (2):

$$
H^{\prime}=\sum_{i=1}^{n} p i \ln p i
$$

Where, H'is Shannon-Wienner Diversity Index, pi is comparison between the number of individual species of type (i) to $\mathrm{H}$ number of total individuals ( $\mathrm{ni} / \mathrm{N}$ ), and $i$ is $1,2,3, \ldots, n$.

Category assessment index $H^{\prime}$ is as follows: $H^{\prime} \leq 1$ is low diversity, $1 \leq \mathrm{H}^{\prime} \leq 3$ is medium diversity, and $\mathrm{H}^{\prime} \geq$ 3 is high diversity.

\section{Uniformity index (E)}

The uniformity index shows the balance of ecosystems. Shannon-Weinner in Team Coordinator Komponen I Tenaga Ahli Biodiversity (2013), stated in equation (3):

$$
E=\frac{H^{\prime}}{H_{\text {max }}^{\prime}} \ldots \ldots \ldots(
$$

Where, $\mathrm{E}$ is uniformity index, $H^{\prime}$ is diversity index, $H_{\text {max }}^{\prime}$ is maximum diversity index $=\ln \mathrm{S}$, and $\mathrm{S}$ is total species.

E value ranges from $0-1$ with the following categories: $0<\mathrm{E} \leq 0.4$ is small uniformity, depressed community; $0.4<\mathrm{E} \leq 0.6$ is medium uniformity, unstable communities; and $0.6<\mathrm{E} \leq 1.0$ is high uniformity, stable community.

\section{Dominance index $(C)$}

The dominance index uses equation (4) according to Simpson, in Team Coordinator Komponen I Tenaga Ahli Biodiversity (2013).

$$
C=\sum_{i=1}^{n} p i^{2}
$$

Where, $\mathrm{C}$ is dominance index, pi is proportion of the number of individuals in fish species, and $\mathrm{I}$ is $1,2,3, \ldots, n$.

Index value ranges from $0-1$ with the following categories: $0<\mathrm{C}<0.5$ is low dominance; $0.5<\mathrm{C}$ $\leq 0.75$ is medium dominance; and $0.75<\mathrm{C} \leq 1.0$ is high dominance.

\section{Data analysis}

Data is analyzed using comparative descriptive method by comparing the fish species caught in each research Station based on relative population abundance, diversity index, dominance, uniformity, and community structure, then presented in the form of legend on the map using ArcMap GIS 10.3 and Microsoft Excel Softwares.

\section{Results and Discussion}

The results are as shown in Table 2. Fish species identified in all study sites were six families consisting of 14 species. They are specified below, along with their status:

Four species of cyprinidae family (28.57\%): Barb (B. balleroides), Hampala barb ( $H$. macrolepidota is least concern (Ahmad, 2019; Herawati et al., 2019), Common carp (C. carpio) is vulnerable (Freyhof and Kottelat, 2008; Herawati et al., 2019), Common barb [M. marginatus) is least concern (Herawati et al., 2019; Vidthayanon, 2012b).

Five species of cichlidae family (35.71 \%): Nile tilapia (O. niloticus) is least concern (Herawati et al., 2019; Snoeks et al., 2018), Mozambique cichlid (O. mossambicus) is near threatened (Cambray and Swartz, 2000; Herawati et al., 2019), Banded jewel cichlid [Hemichromis elongatus (Guichenot, 1861)] is least concern (Herawati et al., 2019; Marshall et al., 2010), Pastel chiclid [Amphilophus alfari (Meek, 1907)], Midas chiclid [Ampbilophus citrinellus 
Gunther 1864)].

Two species of bagridae family (14.2\%): Macrones (M. nigriceps), Long whiskers catfish (M.gulio), is least concern (Herawati et al., 2019; Ng, 2010).

One species of each channidaefamily,mastacembelidae family, and loricariidae family $(7.1 \%)$ : respectively Snakehead [Channa gachua (Hamilton, 1822)] is least concern (Herawati et al., 2019; Chaudhry, 2010), Fire eel (M. erythrotaenia) is least concern (Herawati et al., 2019; Vidthayanon, 2012a), and Pleco (H. pardalis) (Table 2).

This result is different from Yuanda (2012), which states that the types of fish in the Cimanuk River are eight families of fourteen species, namely families: cyprinidae, chiclidae, bagridae, loricaridae, chanidae, cobitidae, osphronomidae, and poecilidae. Fish that were not found at the time of the study were from the families cobitidae, osphronomidae, and poecilidae; but there is a similarity in the results of the study which shows that the number of species from the family cyprinidae and chiclidae is relatively large when compared to the number of fish species from the family bagridae, loricaridae, and chanidae. The results showed that there were additional species from the chiclidae family, namely Banded jewel chiclid [Hemichromis elongatus (Guichenot, 1861)], Pastel chiclid [Amphilophus alfari (Meek, 1907)], and Midas chiclid (A. citrinellus), this fish is introduced ornamental fish.

In the Cimanuk River, there are five species of cichlids found, relatively more than in the Indus River at Taunsa Barrage in Punjab, Pakistan which only three species, namely Nile tilapia (O. niloticus), Mozambique cichlid (O. mossambicus) and [Oreochromis aureus (Steindachner, 1864)] (Muhammad et al., 2017).

Table 2: Fish type and status of Cimanuk River fish during research.

\begin{tabular}{|c|c|c|c|c|c|c|c|c|c|}
\hline \multirow[t]{2}{*}{ Family } & \multirow[t]{2}{*}{$\begin{array}{l}\text { Local } \\
\text { name }\end{array}$} & \multirow[t]{2}{*}{ Common name } & \multirow[t]{2}{*}{$\begin{array}{l}\text { Scientific } \\
\text { name }\end{array}$} & \multicolumn{2}{|c|}{ Base on its origin } & \multicolumn{4}{|c|}{$\begin{array}{l}\text { Base on protected, prohibited, and } \\
\text { invasive species }\end{array}$} \\
\hline & & & & Endemic & Introduced & $\begin{array}{l}\text { Invasive } \\
\text { Endemic }\end{array}$ & $\begin{array}{l}\text { Invasive } \\
\text { Alien }\end{array}$ & Protected & Prohibited \\
\hline \multirow[t]{4}{*}{ Cyprinidae } & Lalawak & Barb & $\begin{array}{l}\text { Barbonymus } \\
\text { balleroides }\end{array}$ & $\checkmark$ & & & & & \\
\hline & Hampal & Hampala barb & $\begin{array}{l}\text { Hampala } \\
\text { macrolepidota }\end{array}$ & $\checkmark$ & & & & $\checkmark$ & \\
\hline & Mas & Common carp & Cyprinus carpio & & $\checkmark$ & & $\checkmark$ & & \\
\hline & Genggehek & Common barb & $\begin{array}{l}\text { Mystacoleucus } \\
\text { marginatus }\end{array}$ & $\checkmark$ & & & & $\checkmark$ & \\
\hline \multirow[t]{5}{*}{ Chiclidae } & Nila & nile tilapia & $\begin{array}{l}\text { Oreochromis } \\
\text { niloticus }\end{array}$ & & $\checkmark$ & & $\checkmark$ & & \\
\hline & Mujair & $\begin{array}{l}\text { Mozambique } \\
\text { tilapia }\end{array}$ & $\begin{array}{l}\text { Oreochromis } \\
\text { mossambicus }\end{array}$ & & $\checkmark$ & & $\checkmark$ & & \\
\hline & Golsom & $\begin{array}{l}\text { Green terror } \\
\text { chiclid }\end{array}$ & $\begin{array}{l}\text { Aequidens } \\
\text { rivulatus }\end{array}$ & & $\checkmark$ & & $\checkmark$ & & $\checkmark$ \\
\hline & $\begin{array}{l}\text { Oscar } \\
\text { barred }\end{array}$ & Pastel chiclid & $\begin{array}{l}\text { Amphilophus } \\
\text { alfari }\end{array}$ & & $\checkmark$ & & $\checkmark$ & & $\checkmark$ \\
\hline & red devil & Midas chiclid & $\begin{array}{l}\text { Amphilophus } \\
\text { citrnellus }\end{array}$ & & $\checkmark$ & & $\checkmark$ & & $\checkmark$ \\
\hline \multirow[t]{2}{*}{ Bagridae } & Keting & $\begin{array}{l}\text { Catfish/ } \\
\text { Macrones }\end{array}$ & $\begin{array}{l}\text { Mystus } \\
\text { nigriceps }\end{array}$ & $\checkmark$ & & & & & \\
\hline & Senggal & Tropical catfish & Mystus gulio & $\checkmark$ & & & $\checkmark$ & & \\
\hline Channidae & Bogo & Snakehead & Channa gachua & $\checkmark$ & & $\checkmark$ & & & \\
\hline $\begin{array}{l}\text { Mastacem- } \\
\text { belidae }\end{array}$ & Berod & Fire eel & $\begin{array}{l}\text { Mastacembelus } \\
\text { erythrotaenia }\end{array}$ & $\checkmark$ & & & & $\checkmark$ & \\
\hline Loricariidae & Sapu-sapu & Plecos & $\begin{array}{l}\text { Pterygoplichthys } \\
\text { pardalis }\end{array}$ & & $\checkmark$ & & $\checkmark$ & & $\checkmark$ \\
\hline \multicolumn{4}{|c|}{ Percentage (\%) } & $50 \%$ & $50 \%$ & $7 \%$ & $50 \%$ & $21 \%$ & $28.6 \%$ \\
\hline
\end{tabular}


Table 2 shows that the proportion of both original fish and introduced fish in Cimanuk River is balanced. The original fish are Barb, Hampala barb, Common barb, Snakehead, Catfish macrones, Tropical catfish, and Fire eel. As for foreign fish, there are common Carp, Nile tilapia, Mozambique chiclid, Banded jewel chiclid, Chiclid pastel, Midas chiclid, and Plecos. Barb, Common barb, and Fire eel are indigenous fish of Cimanuk River and therefore protected as they are listed in LC (least concern) category of IUCN Red List (2012). Snakehead fish is an invasive species of the river's native fish. Invasive foreign species found in the river - which are supposedly prohibited in accordance with PERMEN KP/No.41/2014 includes Common carp, Nile Tilapia, Mozambique chiclid, Banded jewel chiclid, Chiclid pastel, Midas chiclid, and Plecos. According to Atmaja et al. (2014), fish of alien species have tendencies to be aggressive in defending their breeding areas, protecting their children, forcing reproductive strategies and antagonistic behavior in maintaining spawning space, competing in feed utilization resources, and hunting as predators.

Relative abundance is the proportion of each species of all individuals within a community (Campbell and Reece, 2010). Figure 1 shows that: (i) at Station
$\mathrm{I}$, the highest relative abundance of $36 \%$ is Tilapia nile fish, followed by $14 \%$ of Snakehead and Pleco fish, then $9 \%$ of Barg hollowed fish and Banded jewel chiclid, while the lowest is $5 \%$ of Common carp fish, Mozambique chiclid, Chiclid pastel, and Midas chiclid. Only two species of native fish - Barb and Hamlet snakehead - were caught; (ii) at Station II, the highest relative abundance of $22 \%$ is Nile tilapia, Barb and Barb hampala, while the lowest is $11 \%$ of common Barb fish, Tropical catfish and Plecos. Four species of native fish were caught: Barb, Hampala barb, Common barb, and Tropical catfish;

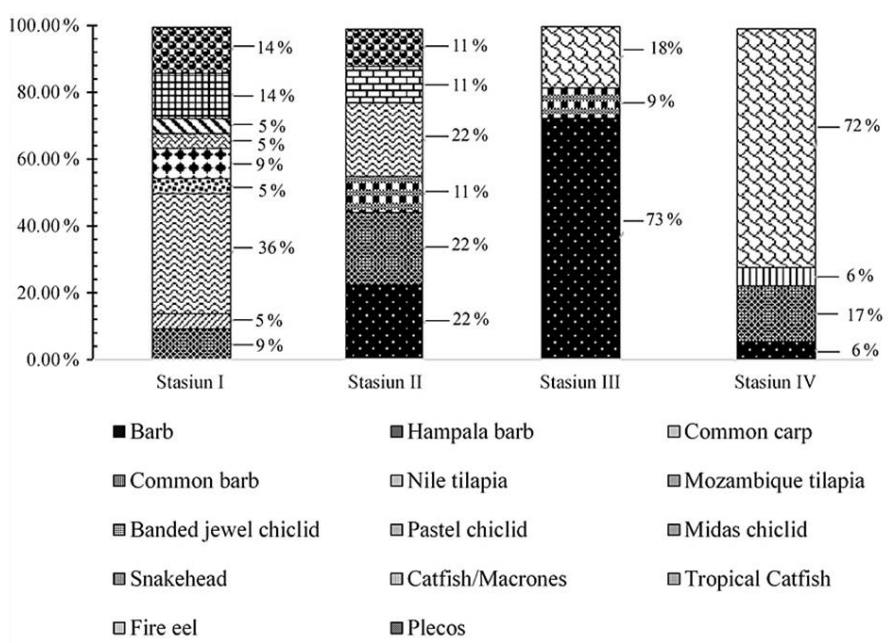

Figure 1: Relative abundance of fish in Cimanuk River.

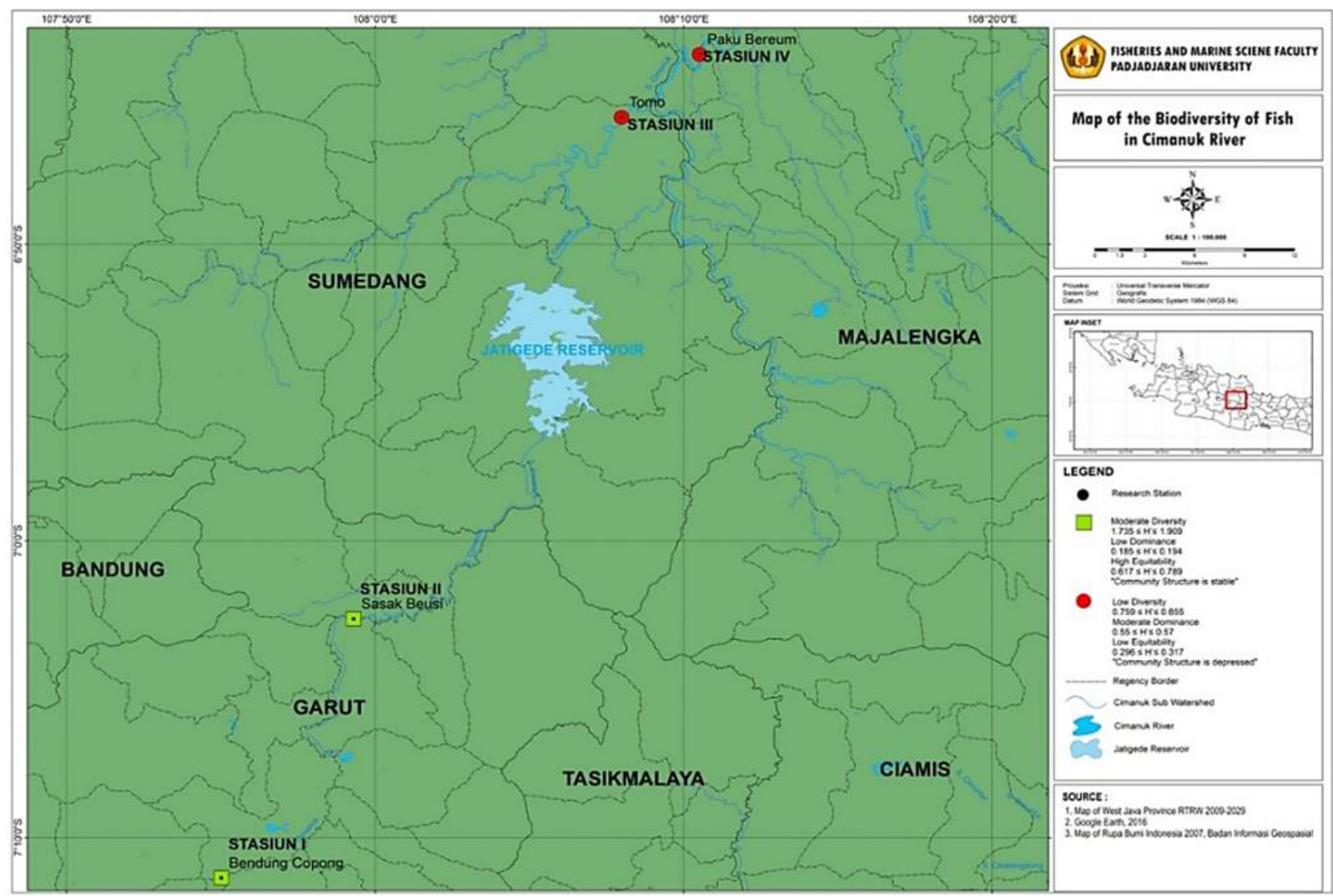

Figure 2: Map of fish diversity in Cimanuk River before and after rainy season. 
(iii) at Station III, the highest relative abundance of $73 \%$ is barb and $18 \%$ of Fire eel, whereas the lowest is $9 \%$ of Common barb fish. Three species of native fish - Barb, Common barb, and Fire eel - were caught; and (iv) at Station IV, the highest relative abundance of $72 \%$ is Fire eel and $17 \%$ of Hampala barb, whereas the lowest is $6 \%$ of Barb and Catfish/macrones. Four species of native fish - Hampala barb, Fire eel, Barb, and Catfish/macrones - were caught.

This finding is consistent with Gonawi (2009) that large and grouped individuals instigate higher rates of abundance. Retrieved in large numbers in each observation, their species have the highest rates of abundance due to their ability to adapt and to utilize the potential of existing resources to make ends meet.

Figure 2 shows the result of calculation. Fish diversity of Stations I and II are consistent with ShannonWienner criterion index $1.735 \leq \mathrm{H}^{\prime} \leq 1.909$, low dominance with index $0.185 \leq \mathrm{C} \leq 0.194$, high uniformity with index $0.617 \leq \mathrm{E} \leq 0.789$, indicating stable fish community structure. The results of the analysis are depicted in the map in the form of light green square symbols. Stations III and IV have low diversity with index $0.759 \leq \mathrm{H}^{\prime} \leq 0.855$, medium dominance with index $0.55 \leq \mathrm{C} \leq 0.57$, low uniformity with index $0.296 \leq \mathrm{E} \leq 0.317$, indicating depressed fish structure community. The results of the analysis are depicted in the map in the form of red circle symbols.

The structure of the fish community at stations III and IV that is stressed should be undertaken for aquaculture to meet nutritional needs and increase fishermen's value-added initiatives, as was done in Kwara State, North Central Nigeria, namely recommended that robust training programs and advisory services should be packaged by extension organizations and other stakeholders for fish farmers in the major areas of capacity deficiencies indicated so as to enhance their use of value addition initiatives from production to marketing (David et al., 2017).

Jatigede Reservoir cuts Cimanuk River flow, and it affects the movement of fish which consequently causes differences in fish community structure along the river upstream and downstream the dam. Barb fish found in Station III are allegedly ones living in Jatigede Reservoir, which are carried by the waste water when the spillway was opened. Station IV, of which water is sandy mud, is dominated by Firefish. This fact goes well with Sentosa and Adisukma (2011) research finding that many Firefish are found in the waters with sandy and muddy substrate.

Krebs (1989) has mentioned that the greater the value of uniformity $(\mathrm{E})$ is, the greater the uniformity of a population. Low uniformity indexes indicate low individual distribution and population domination, which can be the effect of the presence of one or more other species with high individual numbers.

Fish diversity of Cimanuk River is strongly supported by the quality of river waters, since both physical and chemical properties of waters affect the survival ability of fish either directly or indirectly. The factors may include current, temperature, $\mathrm{pH}, \mathrm{DO}$, depth, substrate, light transparency, ammonia content, and nitrite content as shown in Table 3.

Table 3: Water quality Cimanuk River.

\begin{tabular}{|c|c|c|c|c|c|c|c|c|c|c|}
\hline \multirow[t]{2}{*}{ Parameter } & \multirow[t]{2}{*}{ Unit } & \multicolumn{2}{|c|}{ Station I } & \multicolumn{2}{|c|}{ Station II } & \multicolumn{2}{|c|}{ Station III } & \multicolumn{2}{|c|}{ Station III } & \multirow{2}{*}{$\begin{array}{l}\text { Water quality std } \\
\text { for fisheries* }\end{array}$} \\
\hline & & Dec'17 & Jan'18 & Dec'17 & Jan'18 & Dec'17 & Jan'18 & Dec'17 & Jan'18 & \\
\hline Current & $\mathrm{m} \mathrm{s}^{-1}$ & 1.02 & 0.60 & 0.91 & 0.78 & 0.7 & 0.57 & 0.83 & 0.69 & - \\
\hline Temperature & ${ }^{\circ} \mathrm{C}$ & 25 & 25.4 & 25.2 & 26.5 & 25.7 & 27.4 & 25 & 26.5 & Deviation $3^{\circ}$ \\
\hline Light penetration & $\mathrm{cm}$ & 22 & 35 & 25 & 28 & 27 & 31 & 22 & 28 & $>25$ \\
\hline Depth & $\mathrm{m}$ & 2.5 & 2.5 & 3.8 & 3.8 & 4 & 4 & 5 & 5 & - \\
\hline Substrate & - & \multicolumn{2}{|c|}{ Mud, sand, rocks } & \multicolumn{2}{|c|}{ Mud, sand, rocks } & \multicolumn{2}{|c|}{ Mud, sand, clay } & \multicolumn{2}{|c|}{ Mud, sand } & \\
\hline $\mathrm{pH}$ & - & 7.97 & 8.01 & 7.65 & 7.99 & 7.73 & 7.69 & 7.99 & 7.84 & $6-9$ \\
\hline $\mathrm{DO}$ & $\mathrm{mg} \mathrm{L} \mathrm{L}^{-1}$ & 6.3 & 5.4 & 6.1 & 5.2 & 5.5 & 4.8 & 5.5 & 4.6 & $>3$ \\
\hline Ammonia & $\mathrm{mg} \mathrm{L} \mathrm{L}^{-1}$ & 0.006 & 0.007 & 0.015 & 0.006 & 0.037 & 0.006 & 0.009 & 0.017 & $<0.02$ \\
\hline Nitrite & $\mathrm{mg} \mathrm{L} \mathrm{L}^{-1}$ & 0.111 & 0.007 & 0.046 & 0.009 & 0.048 & 0.057 & 0.025 & 0.164 & $<0.06$ \\
\hline
\end{tabular}


The water quality of Cimanuk River (Table 3) strongly supports fish life. In rainy season, it meets the quality standard of Water Quality Index (WQI) class III. Parameters that exceed the above standard are light penetration at Station I, ammonia $\left(\mathrm{NH}_{3}-\mathrm{N}\right)$ content at Station III, and nitrite contents at Stations I and IV.

Light penetration at Station I is low due to pollutants washed into the river by surface runoff. Turbidity is mostly caused by larger materials from the surface layer of soil which are carried by the flow of water during rain and suspended in rivers. At the time the amount of suspended materials was not specifically measured, brown water color already indicated that the concentration was high. The high turbidity of Cimanuk River water was more likely caused by sand mining activity - eroded soil was then carried by the rainwater downstream. According to SNI, the ideal light penetration for fish cultivation of Cyprinidae group is $(25 \mathrm{~cm}$ to $80 \mathrm{~cm})$ and Chiclidae is $(30 \mathrm{~cm}$ to $40 \mathrm{~cm}$ ). High rainfall contributed in the low light penetration result in December 2017, making it unable to meet the specified quality standard.

Ammonia is the product of decomposition process. A large number of residents throw their garbage into Cimanuk River. Additionally, Luvi (2000) reported that certain factories in Station III area disposed of their waste into the river as well. They are likely the reasons why the ammonia content of the river is high.

Nitrites in water bodies come from industrial waste and domestic waste (Effendi and Wardiatno, 2015). Excessive nitrite levels occurred at Station I during observations in December 2017 and at Station IV in a January 2018 observation. The high nitrite level at Station I was allegedly due to reshuffle activity from ammonia to nitrites performed by Nitrosomonas bacteria derived from soy sauce and chicken feather waste. If nitrite compounds in the waters exceed the ability of the organism to neutralize it, it would be dangerous; nitric compounds would inhibit the entry of oxygen into the body of aquatic organisms, which subsequently enters the gills. Since most fish caught in these areas are of chiclidae, it is conclusive that chiclidae species has a high tolerance of nitrite and turbidity.

\section{Conclusions and Recommendations}

fish and foreign fish, with the same 1:1 proportion. Hampala barb, Common barb, and Fire eel are the river's native fish and need to be protected with low risk status to avoid extinction. Mozambique cichlid, Nile tilapia, Pastel chichlid, and Midas chiclid are foreign invasive fish groups that may need controlling.

While fish diversity status is of medium diversity, low dominance, high uniformity, and stable fish community structure prior to rainy season, it changes into low diversity index, moderate dominance, low uniformity, and depressed fish structure community during rainy season.

\section{Acknowledgments}

This research is funded from the flagship research of Universitas Padjadjaran (Unpad Lecturer Dissertation Research) and The Ministry of Research, Technology and Higher Education of Republic Indonesia, based on the Letter of Agreement No. 2214/UN6.M/ LT/2019.

\section{Novelty Statement}

Fish diversity of Cimanuk River upstream Jatigede Reservoir was different from downstream. The structure of fish community before the reservoir was stable, while one after the reservoir was stressed. This difference should be caused by fish being unable to migrate, since the dam's construction is not equipped with a fish way. Another cause should be the concentration of ammonia downstream the dam was so high that it exceeded the threshold limit for fisheries.

\section{Author's Contribution}

TH conceived and designed the study, performed definition of intellectual content, literature search, experimental studies, data acquisition, data analysis, statistical analysis, and manuscript preparation. IA, AY and IR performed definition of intellectual content, literature search, experimental studies, and manuscript review. AS performed experimental studies, data analysis, and statistical analysis. RHS and $\mathrm{HJ}$ explored and elaborated definition of intellectual content, literature search, manuscript editing, manuscript review, and guarantor.

The fish living in Cimanuk River are generally of native 
Conflict of interest

The authors herewith declare that no conflict of interests regarding the publication of this manuscript.

\section{References}

Ahmad, A.B. 2019. Hampala macrolepidota. The IUCN red list of threatened species 2019: e.T181255A1714119.

Amzah, B., R. Jajuli, N.A.L. Jaafar, S.Z Jamil, S.N.A.B. Hamid, N.I. Zulkfili., N.A. Ismail, A.B. Kadir, E.E.E. Ariff and R. Baki. 2018. Application of ecological engineering to increase arthropod's diversity in rice ecosystem. Malaysian Appl. Biol., 47: 1-7.

Andani, A., T. Herawati and H. Hamdani. 2017. Identification and inventory of adaptive fish in jatigede reservoir at initial inauguration stage. J. Perikanan Kelautan, 8: 28-35.

Atmaja, P., R.P.Tampubolon, M.F. Rahardjo and K. Krismono. 2014. Potensi ancaman invasif ikan oskar (Amphilophus citrinellus) di waduk Ir. H. Djuanda, Jawa Barat [Potency of midas cichlid threat invasion (Amphilophus citrinellus) in Ir. H. Djuanda reservoir, West Java]. Widyariset, 17: 311-321.

Cambray, J., and E. Swartz. 2007. Oreochromis mossambicus. The IUCN Red list of threatened species 2007: e.T63338A12659743.

Campbell, N.A., and J. B. Reece. 2010. Biology. Erlangga, Jakarta.

Chaudhry, S. 2010. Channa gachua. The IUCN red list of threatened species 2010: e.T166123A6179047.

David O.O., O.A. Adetokunbo, F.O. Olayinka, T.O. Oluwaseun and O.O. Idowu. 2017. Training needs of fish farmers on value addition initiative in Kwara Sate, Nigeria. Sarhad J. Agric., 33: 14-21. https://doi.org/10.17582/journal. sja/2017.33.1.14.21

Effendi, Y. and Y. Wardiatno. 2015. Water quality status of Ciambulawung River, Banten Province, based on pollution index and NSFWQI. Proc. Environ. Sci., 24: 228-237. https:// doi.org/10.1016/j.proenv.2015.03.030

Freyhof, J. and M. Kottelat. 2008. Cyprinus carpio. The IUCN red list of threatened species 2008: e.T6181A12559362.

Gonawi, G.R.2009.Habitat and nekton community structure in Cihideung River, Bogor, West Java. Master Thesis, Bogor Agricultural Institute,
Bogor.

Herawati, T., R. Mustikawati, S.Y. Diliana and A. Andani.2017. Types of fish in Jatigede Reservoir initial period inundation (2015-2017). Unpad Press, Bandung, Indonesia.

Herawati, T., R. Aghisni and W. Gema. 2019. Types of freshwater fish in West Java and protection status. Unpad Press, Bandung, Indonesia.

Kottelat, M. 2013. The fishes of the inland waters of Southeast Asia: A catalogue and core bibliography of the fishes known to occur in freshwaters, mangroves and estuaries. Raffles Bull. Zool., 27: 1-663.

Krebs, C.J. 1989. Ecological methodology. Harper \& Row Publisher, New York.

Luvi, D.M. 2000. Aspects of reproduction and food habits fish lalawak (Barbodes balleroides) in Cimanuk River, Sumedang West Java. Magister Thesis, Fakultas Perikanan dan Ilmu Kelautan, Insitut Pertanian Bogor, Bogor.

Marsha '11, B., T. Moelants and D. Tweddle. 2010. Hemichromis elongatus. The IUCN Red List of Threatened Species 2010: e.T181750A7724336.

Minister of Maritime Affairs and Fisheries of the Republic of Indonesia. 2009. Types of fish and areas of restocking fish catching fish based on aquaculture. Jakarta, Indonesia.

Minister of Maritime Affairs and Fisheries of the Republic of Indonesia. 2015. Technical guiddelines for mapping the distribution of protected, prohibited and invasive biological agents in Indonesia. Jakarta, Indonesia.

Minister of Maritime Affairs and Fisheries of the Republic of Indonesia. 2014. List of pisces potentially as invasive species in Indonesia. Jakarta, Indonesia.

Minister of Maritime Affairs and Fisheries of the Republic of Indonesia. 2014. Regulation of the Minister of Marine Affairs and Fisheries of the Republic of Indonesia No. 41 of 2014 concerning import prohibiton of hazardous fish species from overseas into the territory of Republic Indonesia. Jakarta, Indonesia.

Muhammad, H., Z. Iqbal, and S. Saleemi. 2017. Diversity and distribution of fish fauna of Indus River at Taunsa Barrage in Punjab, Pakistan. Pakistan J. Zool., 49: 149-154. https://doi. org/10.17582/journal.pjz/2017.49.1.149.154

$\mathrm{Ng}, \mathrm{H} . \mathrm{H} .2010$. Mystus gulio. The IUCN Red List of Threatened Species 2010: e. T166633A6251601. PPRI, 2001. Government regulation No. 82/2001 
on water quality management and water pollution control. Jakarta, Indonesia.

Sentosa, A.A., and A. Adisukma. 2011. Fire eel Fish resources conservation (Mastacembelus sp.) In Cimanuk River central part, Sumedang Regency. In: Prosiding Forum Nasional Pemacuan Sumberdaya Ikan III, Bandung, Indonesia, pp. 1-13.

Snoeks, J., J. Freyhof, D. Geelhand and A. Hughes. 2018. Oreochromis niloticus. The IUCN Red List of Threatened Species 2018: e.T166975A49922878.

Sugiyono, 2012. Qualitative quantitative research methods and R\&D. Alfabeta, Bandung.

Team Coordinator Komponen I Tenaga Ahli
Biodiversity. 2013. Biodiversity survey planning and design - Proyek Citarum watershed management and biodiversity conservation. ICWRMIP-CWMBC - Integrated Citarum Water Resources Management Investment Program, Bandung, Indonesia.

Vidthayanon,C.2012a.Mastacembeluserythrotaenia. The IUCN red list of threatened species 2012: e.T180888A1673971.

Vidthayanon, C. 2012b. Mystacoleucus marginatus. The IUCN red list of threatened species 2012: e.T180759A1659643.

Yuanda, M.A. 2012. Fish community structure in Upper Cimanuk River Garut. J. Perikanan Kelautan, 3: 229-236. 